\title{
Implementeringsforskning: vitenskap for forbedring av praksis
}

\author{
Signe Flottorp ${ }^{1}$ og Eivind Aakhus ${ }^{1,2}$ \\ 1) Seksjon for forebyggende, helsefremmende og organisatoriske tiltak, Nasjonalt kunnskapssenter for helsetjenesten \\ 2) Sykehuset Innlandet, 2312 Ottestad \\ Korrespondanse: Signe Flottorp, e-post: signe.flottorp@kunnskapssenteret.no Telefon: 99504376
}

\begin{abstract}
SAMMENDRAG
Medisinsk forskning har ført til store framskritt de siste tiårene. Det er investert mye mer ressurser på basalforskning og klinisk forskning enn på å utvikle og evaluere metoder for å sikre at pasientene får nytte av forskningen. Formålet med implementeringsforskning er å redusere gapet mellom forskning og praksis, ved å utvikle og evaluere tiltak som kan sikre at behandlingen som pasientene mottar er kunnskapsbasert, at den er omsorgsfull og av god kvalitet.

I denne artikkelen gjør vi rede for hva implementering og implementeringsforskning er. Vi belyser historikken til denne unge vitenskapen, og illustrerer mangfoldet i de faglige tilnærmingene og begrepene som brukes om det å få forskning brukt i praksis. Det finnes en rekke teorier om endring av atferd, både på individnivå og på organisatorisk nivå. Teoriene er imidlertid i liten grad testet empirisk, særlig når det gjelder å endre atferd i helsetjenesten.

Systematiske oversikter over metodisk gode studier er den beste kilden til informasjon om effekt av implementeringstiltak. The Cochrane Effective Practice and Organisation of Care Group (EPOC) er en viktig kilde for slike oversikter. De systematiske oversiktene som er utarbeidet på dette feltet viser at passive dissemineringstiltak har begrenset effekt, mens mer aktive tiltak kan ha liten til moderat effekt. Det er ofte betydelig variasjon i effekt på tvers av studiene. Det er derfor viktig å få bedre kunnskap om hvilke faktorer som kan forklare slike forskjeller i effekt.

Vi gir eksempler på norske implementeringsstudier, og refererer bidrag fra forskere ved Kunnskapssenteret. Implementeringsforskningen kan, hvis den lykkes, sikre pasientene bedre behandling.
\end{abstract}

Flottorp S, Aakhus E. Implementation research: science for improving practice. Nor J Epidemiol 2013; 23 (2): 187-196.

\section{ENGLISH SUMMARY}

Medical research has led to major advances in recent decades. More resources have been invested in basic and clinical research than into the development and evaluation of methods to ensure that patients benefit of research findings. The purpose of implementation research is to reduce the gap between research and practice, by developing and evaluating measures to ensure that the treatment patients receive is evidencebased, caring and of high quality.

In this article, we briefly explain implementation and implementation research. We illustrate the history of this young science, and the diversity of academic approaches and concepts used when trying to get research into practice. There are a number of theories about behavioural change, both at the individual and organisational level. The theories are, however, rarely tested empirically, especially when it comes to changing behaviour in the health services.

Systematic reviews of methodologically rigorous studies are the best source of information about the effects of implementation interventions. The Cochrane Effective Practice and Organisation of Care Group (EPOC) is a major source of such reviews. The systematic reviews that have been produced in this area indicate that passive dissemination has limited impact, while more active interventions may have small to moderate effects. There is often considerable variation in the effects across studies. It is therefore important to gain better knowledge of the factors that may explain such effect-differences.

We give examples of Norwegian implementation studies, and refer contributions from researchers at the Norwegian Knowledge Centre for the Health Services. Implementation research has the potential, if successful, to ensure that patients receive better health care.

This is an open access article distributed under the Creative Commons Attribution Licence, which permits unrestricted use, distribution, and reproduction in any medium, provided the original work is properly cited.

\section{GAP MELLOM FORSKNING OG PRAKSIS}

Medisinsk forskning har ført til nye tiltak innen diagnostikk, forebygging, behandling og rehabilitering som har revolusjonert tilbudet innen klinisk medisin. Pasi- enter særlig i den rike del av verden kan nyte godt av disse store framskrittene.

Helsetjenesten sysselsetter mange kompetente fagfolk som gir pasientene både omsorgsfull og faglig god hjelp. I Norge rapporterer de fleste pasientene at de er 
fornøyde med spesialisthelsetjenesten, fastlegene og tilbudet i kommunene.

Men nyvinningene i medisinsk forskning bidrar ikke til å bedre folks helse hvis de ikke tas i bruk. Veien fra viktige forskningsfunn til endringer i praksis er uforutsigbar, tilfeldig og ofte langsom. Samtidig som medisinsk basalforskning og klinisk forskning har gitt oss nye muligheter, blir manglene i helsetjenesten tydeligere.

Vi har ikke tilstrekkelig gode systemer for å sikre at helsetjenester er basert på den beste tilgjengelige forskning. På den ene siden er det et problem at det tar for lang tid før dokumenterte tiltak tas i bruk i praksis. På den andre siden er det vanskelig å hindre at entusiastiske leger og annet helsepersonell tar i bruk nye metoder som ikke er godt nok evaluert. Pasienter får ikke alltid den mest effektive behandlingen, basert på tilgjengelig forskning. Dette kan innebære at pasienter får tilbud om diagnostikk og behandling som er uten effekt eller som kan gjøre mer skade og nytte, eller at de ikke får tilbud om tiltak med dokumentert effekt. Pasienter kan risikere å få både feilaktige, for mye og for lite helsetjenester. En spørreundersøkelse i regi av Commonwealth Fund i 2012 viste at 33,5 \% av norske fastleger mente at pasientene fikk for mye behandling (1). Det er for eksempel et overforbruk av antibiotika ved luftveisinfeksjoner, og av bildediagnostikk ved muskel- og skjelettlidelser. Det er økende oppmerksomhet rettet mot skadelige virkninger av overdiagnostikk og overbehandling, og dette er tittel og tema i en rapport utarbeidet av Helsedirektoratet på oppdrag fra Helse- og omsorgsdepartementet (2). Det er bekymringsfullt at friske personer feilaktig kan bli stemplet som syke ved utstrakt bruk av laboratorieprøver og bildediagnostikk. Forbruket av blodtrykks- og kolesterolsenkende medikamenter har økt sterkt de seinere år. Fortsatt er det imidlertid slik at en del pasienter som har liten total risiko behandles unødvendig med medisiner. Samtidig finnes det pasienter med høy risiko for hjerte- og karsykdommer, som ikke har fått anbefalt forebyggende medikamentell behandling.

Kvaliteten i helsetjenesten er også mangelfull på andre måter: mange pasienter opplever ikke å bli sett og møtt på en god måte, men lider under mangel på empati og forståelse. Leger og annet helsepersonell kan svikte i sin kommunikasjon med pasientene, slik at pasientene mister nødvendig tillit til helsetjenesten. Informasjonen til pasientene er ofte mangelfull, enten ved at den ikke blir gitt $\mathrm{i}$ det hele tatt, eller ved at helsepersonell ikke forsikrer seg om at pasienten har oppfattet informasjonen rett. Pasienter med sammensatte problemer eller med tilstander som krever innsats fra ulike typer helsepersonell, opplever ofte manglende koordinering og dårlig oppfølging. Moderne medisin kan innebære betydelig risiko, men pasientsikkerheten er ikke alltid godt nok ivaretatt. For eksempel kan sviktende kommunikasjon om medisinbruk ved innleggelse på sykehus føre til feilmedisinering (3). Bivirkninger av legemidler er vanlig, det kan føre til sykehusinnleggelse og i verste fall ha dødelig utgang (4). Mye av dette kan forebygges (5).

Det er et for stort gap mellom den beste tilgjengelige kunnskapsbaserte praksis og den behandling som helsetjenesten tilbyr $(6,7)$. I den vestlige verden har vi brukt mye ressurser på medisinsk basalforskning og på klinisk forskning, mens vi har brukt relativt lite på å utvikle og evaluere metoder for å sikre at kunnskapsbaserte tiltak, gode metoder og innovasjoner blir tatt $i$ bruk i tjenestene.

\section{RETNINGSLINJER}

Det publiseres så mye medisinsk forskning at det er umulig for helsepersonell å holde seg faglig oppdatert ved å lese vitenskapelige artikler - noe de færreste har anledning til å bruke særlig mye tid på. Gode retningslinjer kan være til hjelp, som et bindeledd mellom forskning og praksis (8). Retningslinjer er anbefalinger som har til hensikt å optimalisere pasientbehandlingen. De bygger på en systematisk kunnskapsoversikt og en vurdering av fordeler og ulemper ved alternative muligheter for behandling og pleie (9). Retningslinjer kan hjelpe både helsepersonell og pasient til å ta velinformerte beslutninger. De fleste kliniske beslutninger må selvsagt individualiseres, basert på verdier og preferanser til den enkelte pasient. God bruk av retningslinjer er ikke tankeløs kokebokmedisin! Det er viktig å kjenne til forventede effekter av de ulike alternativene for å kunne vurdere om fordeler oppveier ulemper, og om eventuell netto gevinst er verdt kostnadene. Gode retningslinjer inneholder denne typen informasjon, men retningslinjer blir ikke nødvendigvis lest eller brukt de implementeres ikke i klinisk praksis (10).

\section{IMPLEMENTERINGSFORSKNING}

I denne artikkelen vil vi gjøre rede for hva implementeringsforskning er, og hvorfor det er viktig at samfunnet satser på slik forskning. Vi vil gi noen eksempler på norsk implementeringsforskning.

\section{ØKT INTERESSE FOR FORSKNING FOR FORBEDRING}

De siste tiårene har vitenskapelig forskning om hvordan helsetjenesten kan forbedres blitt et viktig forskningsfelt $(11,12)$. Slik forbedringsvirksomhet - og evalueringen av den - har fătt en rekke ulike navn, som f.eks. implementerings-, (kvalitets)forbedrings- og pasientsikkerhetsforskning, samt disse termene som ikke er enkle å oversette til norsk: research utilization, delivery science, knowledge translation (KT) research $(13,14)$. Den tradisjonelle translasjonsforskningen, ofte benevnt T1, er forskningen som handler om å omsette resultater fra basalforskning til klinisk relevant kunnskap (from bench to bedside). Den nye betydningen av begrepet, som gjerne kalles T2, handler om å forske på det å omsette resultater fra klinisk forskning til klinisk praksis (15). 
Implementeringsforskning handler imidlertid ikke bare om det å ta i bruk medisinske nyvinninger. En like stor utfordring er det å sikre at praksis tar opp i seg veletablert kunnskap, og ellers er av god kvalitet. Forskere interesserer seg for kvalitetsforbedring $\mathrm{i}$ helsetjenesten på tvers av ulike akademiske og kliniske fag. Det er etablert flere tidsskrift for dette formålet, f.eks. Implementation Science, BMJ Quality and Safety, og International Journal for Quality in Health Care. Beslutningstakere har begynt å etterlyse mer og bedre forskning på dette området (16-18), og i flere land er det opprettet egne institusjoner for denne type aktivitet, f.eks. Canadian Institutes of Health Research, ZonMW in Nederland og Agency for Healthcare Research and Quality i USA (19).

\section{HisTORIKK}

Interessen for implementeringsforskning i helsetjenesten har økt det siste tiåret, men feltet er ikke nytt, og ikke eksklusivt for medisinen. Rogers bok "Diffusion of innovations" kom forste gang ut i 1962, og har seinere kommet $\mathrm{i}$ fem utgaver (20). Rogers beskriver utviklingen av forskning om spredning av innovasjoner innen en rekke ulike fagfelt som antropologi, sosiologi, landbruk, undervisning, folkehelse og medisinsk sosiologi, kommunikasjon, markedsføring, økonomi, administrasjon og ledelse. Han hevder at fagfeltet har sine røtter i europeisk sosialvitenskap fra omkring 1900. Rogers henter flere av sine eksempler fra landbruket. En studie av spredningen av en hybrid type maiskorn i Iowa fra 1943 regnes som epokegjørende, og denne studien markerte et paradigmeskifte innen forskningen om spredning av innovasjoner.

Innen samfunnsvitenskapene finnes en parallell tradisjon med forskning om policyimplementering. Harald Sætren viser i en litteraturoversikt at de første studier om policyimplementering ble publisert tidlig på 1930tallet (21). De handlet om internasjonal politikk. Seinere kom en rekke avhandlinger om implementering $\mathrm{i}$ utdanningssektoren. Den moderne implementeringsforskningen ble etablert ved en serie policystudier som rettet søkelyset mot problemene ved gjennomføringen av store samfunnsreformer i USA. Sentralt formulerte intensjoner skulle gjennomføres på regionalt og lokalt nivå, men det viste seg at det ofte ikke gikk slik det var planlagt. Dette ble omtalt som "top-down" implementering, og disse studiene gjenspeiler frustrasjonen $\mathrm{i}$ USA over vanskene med å få viktige samfunnsreformer til å fungere. Den mest kjente boka fra denne perioden er Pressman og Wildavskys fra 1973, med den talende tittelen "Implementation: How great expectations in Washington are dashed in Oakland; or, why it's amazing that federal programs work at all, this being a saga of the economic development administration as told by two sympathetic observers who seek to build morals on a foundation of ruined hopes - The Oakland Project" (22).

Sætren tilbakeviser i sin oversikt at implemente- ringsforskning har gått av moten innen samfunnsvitenskapene (21). Forskning om policyimplementering har blitt mer differensiert på flere spesifikke områder som utdanning, helse og miljø. Sætren etterlyser gode systematiske oversikter på feltet, fordi policyforskningen er spredt $\mathrm{i}$ ulike fagspesifikke tidsskrifter eller policytidsskrifter rettet mot enkeltsektorer som f.eks. helsetjenesten. Videre peker han på at kunnskapen på feltet er mangelfull til tross for at det har vært gjennomført mange studier. Det som trengs er kanskje ikke først og fremst flere studier, men bedre studier (21).

\section{KUNNSKAPSBASERT PRAKSIS - OG KUNNSKAPSBASERT IMPLEMENTERING}

Implementeringsvitenskapen i helsetjenesten har først og fremst utviklet seg i kjølvannet av engasjementet for kunnskapsbasert praksis de siste 20 år, og har $\mathrm{i}$ mindre grad bygd på den samfunnsvitenskapelige tradisjonen med studier av policyimplementering (23). Evidence based medicine (EBM), eller kunnskapsbasert praksis, handler nettopp om å bruke forskning, sammen med erfaringer og verdier og preferanser, for å treffe beslutninger både for den enkelte pasient, og på overordnet nivå. Men dette skjer ikke av seg selv.

Implementeringsvitenskapen har interessert seg for å identifisere og vurdere effektene av å påvirke faktorer som kan gjøre det lettere å følge kliniske retningslinjer og forbedre kvaliteten i tjenestene. På samme måte som vi ønsker at diagnostikk og behandling skal baseres på systematiske oversikter over studier som er utført med rigorøse metoder, ønsker vi at tiltak for å forbedre helsetjenesten også bør bygge på systematiske oversikter over utført forskning på de tiltakene vi vurderer å bruke.

\section{DEFINISJON AV IMPLEMENTERINGS- FORSKNING}

Implementeringsforskning innen helse handler altså om vitenskapelige studier av metoder for å fremme opptak av resultater fra forskning i den ordinære helsetjenesten, og derved forbedring av kvaliteten på tjenestene.

Her er en av flere definisjoner på implementeringsforskning:

Implementation research is the scientific study of methods to promote the systematic uptake of clinical research findings and other evidence-based practices into routine practice, and hence to improve the quality (effectiveness, reliability, safety, appropriateness, equity, efficiency) of health care. It includes the study of influences on healthcare professional and organizational behavior (24).

\section{FORBEDRINGSVITENSKAP - RIGORØSE METODER VIKTIG}

Marshall og medarbeidere hevder at "vitenskapen for forbedring" er i det som Kuhn kaller pre-paradigme- 


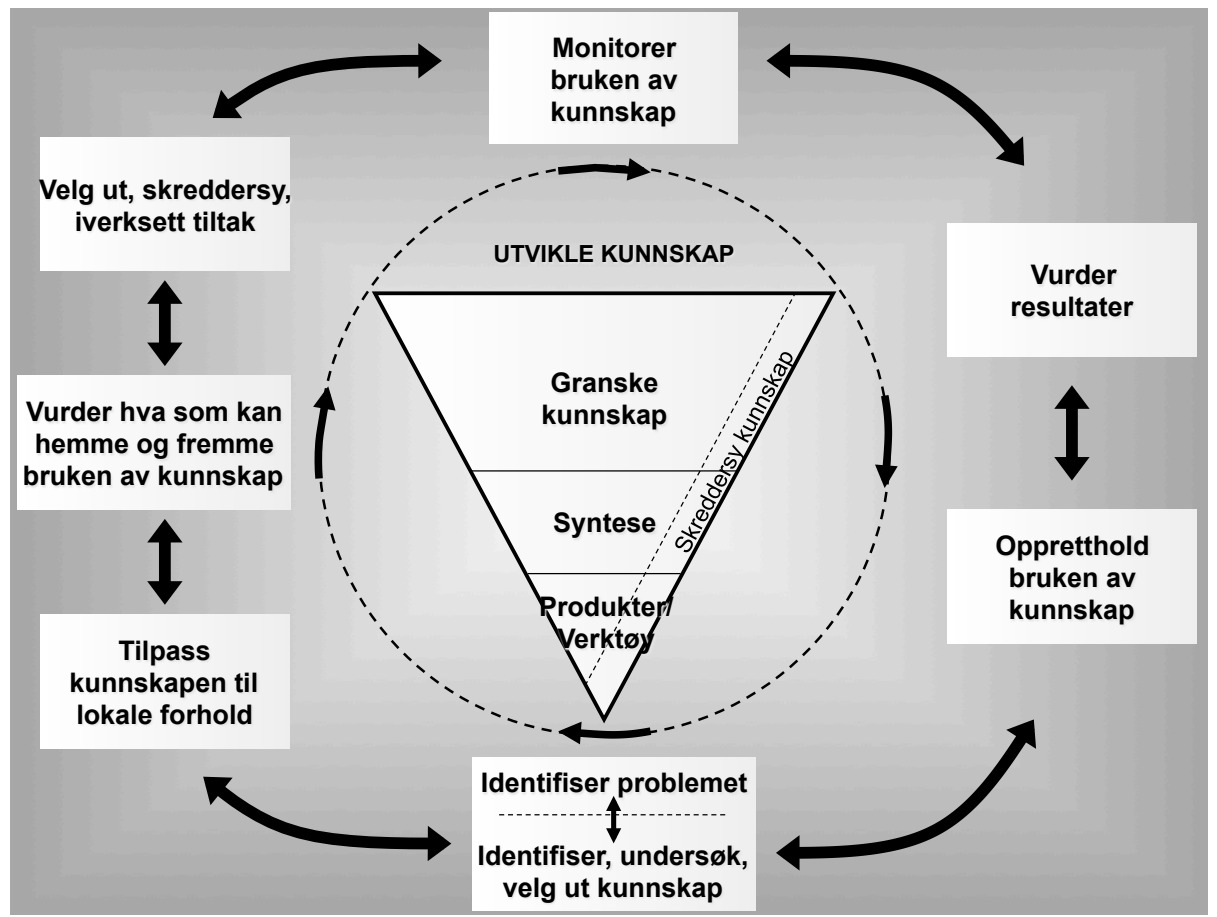

Figur 1. Fra kunnskap til handling.

fasen for et nytt fagområde (25). Et av kjennetegnene på denne fasen er at det mangler en anerkjent definisjon.

Marshall og medarbeidere hevder at altfor mange kvalitetsforbedringsprosjekter er utført slik at det ikke er mulig å si om de faktisk virker. Vitenskap for forbedring er derimot forpliktet på rigorøse metoder og bruk av data av høy kvalitet. Forfatterne etterlyser partnerskap mellom forskere, helsepersonell og folk som jobber med kvalitetsforbedring, og de skisserer en strategi for at forbedringsvitenskapen skal få gjennomslag. Beslutningstakere, helsetjenesten og akademiet må få innsikt i feltet, og forstå at dette kan bety en forskjell for tjenestetilbudet til pasientene. Det må bygges kapasitet og kompetanse i alle ledd fra ledere til helsepersonell i førstelinjen. Vitenskapen for forbedring er preget av en slags motkultur sammenliknet med de tradisjonelle helsetjenester og akademiske disipliner. Det er nødvendig å omdefinere suksesskriterier både $i$ forskningsverdenen (hvor det å utvikle og anvende vitenskapelig dokumentasjon for bruk i praksis ikke blir høyt verdsatt) og i tjenestene (hvor det å utvikle og anvende vitenskapelig dokumentasjon ikke nødvendigvis står høyt i kurs). Et internasjonalt nettverk kan hjelpe forskere til å dele kunnskap og sikre at den utvikler seg på en utadvendt måte, slik Cochranesamarbeidet har bidratt til å sikre grunnlaget for kunnskapsbasert medisin. Marshall og medarbeidere understreker også behovet for å etablere og finansiere sentra for forbedringsvitenskap, med ulike akademiske og kliniske fagområder. De spår at vitenskapen for forbedring i løpet av en tiårsperiode vil bli avgjørende for å sikre tilbud av høy kvalitet til pasientene, så sant en lykkes med en satsning på dette feltet (25).

\section{NOEN IMPLEMENTERINGSMODELLER}

I Rogers' modell beskrives beslutningen om å ta i bruk en innovasjon som en prosess over tid med flere trinn, der implementering er ett av trinnene (20):
1. Kunnskap
2. Overtalelse
3. Beslutning
4. Implementering
5. Bekreftelse

Innovasjoner kan spres gjennom passiv diffusjon eller aktiv disseminering.

Gjennomføring av en policy beskrives gjerne med en liknende idealmodell (23):

1. Identifisering av problem og initiering av policyprosessen

2. Forberedelse

3. Beslutning

4. Implementering

5. Evaluering

Implementeringsforskere har blitt kritisert for å ha en overforenklet forståelse av implementering som en rettlinjet prosess, med bruk av metaforer som at kunnskapen flyter som i en rørledning fra forskerens laboratoriebenk og ut i praksis (26). I virkeligheten er selvsagt både aktive implementeringsprosesser og passiv disseminering av innovasjoner komplekse sosiale fenomener. Forenklede modeller kan imidlertid hjelpe oss til å forstå, studere og fortolke prosessene.

Figur 1 viser modellen "Fra kunnskap til handling" som først ble publisert i artikkelen "Lost in knowledge translation: time for a map?" av Graham og medarbeidere (27). 


\section{SKREDDERSYDDE IMPLEMENTERINGSTILTAK}

Én strategi for å fremme effektiv implementering er at tiltakene "skreddersys". Med dette menes at det utarbeides en tiltakspakke i lys av en analyse av hvilke faktorer som bidrar til å forhindre eller fremme endringer av aktuell praksis (determinanter). Tanken er at implementeringsintervensjoner vil være mer effektive hvis de rettes mot viktige determinanter for praksis. For eksempel fant vi at høyere takster kunne medvirke til økt bruk av telefonkonsultasjoner blant fastleger, som var anbefalt ved henvendelser som gjaldt sår hals og ukompliserte urinveisinfeksjoner (28). I vår tiltakspakke for kvalitetsforbedring inngikk derfor økt telefontakst, sammen med andre tiltak. Riktignok viste det seg at andelen telefonkonsultasjoner ikke gikk opp kanskje var ikke takstøkningen stor nok, eller kanskje var andre faktorer viktigere (29).

EU-prosjektet Tailored implementation for chronic diseases (TICD), har som mål å utvikle bedre metoder for å gjennomføre og evaluere skreddersydde implementeringsintervensjoner, samt å forbedre behandlingstilbudet for pasienter med kroniske sykdommer (se ramme) (30). Gjennom dette prosjektet har vi utarbeidet en sjekkliste for determinanter for praksis, basert på en systematisk oversikt over ulike rammeverk og modeller (31). Denne sjekklisten inneholder 57 faktorer fordelt på sju områder:

- Retningslinjen

- Den enkelte helsearbeider

- Pasienten

- Samhandling mellom helsepersonell

- Insentiver og ressurser

- Kapasitet for organisasjonsmessig endring

- Sosiale, politiske og juridiske forhold

Sjekklisten er ment som en støtte for folk som skal utvikle, gjennomføre og eventuelt evaluere kvalitetsforbedrings- og implementeringstiltak. Sammen med sjekklisten har vi publisert verktøy som skal gjøre det enklere å bruke sjekklisten i implementeringsforskningsprosjekter.

\section{TEORIER OG EMPIRI OM IMPLEMENTERINGSFORSKNING}

Det finnes en rekke teorier om endring av atferd, både på individnivå, på organisatorisk nivå og på systemnivå (32,33). Noen aktuelle teorier er sosial kognitiv teori, teori om læring og forandring, diffusjon av innovasjon, markedsføring, sosial innflytelse, transteoretisk modell for atferdsendring (Readiness for change), Theory of Planned Behavior og Total Quality Management.

Psykologiske teorier har vært mye benyttet for implementeringstiltak rettet mot helsepersonell (33). Mange endringer i helsetjenesten krever imidlertid også organisatoriske endringer. "Readiness for change" er et eksempel på en teori som er testet ut på individnivå, men som også er aktuell for organisasjoner (34).
Det er imidlertid sparsomt med dokumentasjon om holdbarheten av de ulike teoriene, særlig når det gjelder å endre atferd i helsetjenesten.

\section{HVA VET VI OM EFFEKTEN AV ULIKE IMPLEMENTERINGSTILTAK?}

Hva kan vi forvente av effekt ved ulike implementeringstiltak? Hvor mye kan vi få leger og annet helsepersonell til å endre praksis, når vi virkelig prøver?

Det finnes ingen mirakelkur for manglende implementering (35). Systematiske oversikter over metodisk gode studier av implementeringstiltak er den beste kilden til informasjon om forventet effekt. Oppsummering av slike oversikter viser at passiv disseminering av retningslinjer og tradisjonell didaktisk undervisning har liten eller ingen effekt på praksis, mens mer aktive intervensjoner som praksisregistrering og tilbakemelding (audit og feedback), påminnere og praksisbesøk har større effekt (36-38). Det er imidlertid ofte stor variasjon i effektene på tvers av studiene. Det er derfor viktig å få mer kunnskap om faktorene som øker muligheten for at implementeringstiltaket skal virke.

En oppdatert oversikt over effektene av praksisregistrering og tilbakemelding inkluderte 140 randomiserte kontrollerte studier, og fant at helsepersonell $\mathrm{i}$ intervensjonsgruppen fulgte retningslinjene $4,3 \%$ (prosentpoeng) mer enn kontrollgruppen (medianverdi; interkvartil bredde fra $0,5 \%$ til $16 \%$ ) (39). Oversikten fant holdepunkter for at man muligens kan forvente større effekt av praksisregistrering og tilbakemelding hvis helsepersonellet har en dårlig praksis i utgangspunktet, at personen som er ansvarlig for praksisregistrering og tilbakemelding er en kollega eller veileder

Tailored Implementation for Chronic Diseases (TICD).

TICD er et eksempel på hvordan implementeringsforskning rettet mot komplekse helsesystemer og sykdomsgrupper kan foregå. Prosjektet er et EU-støttet samarbeidsprosjekt der fem europeiske land (Norge, Tyskland, England, Polen og Nederland) undersøker effekter av å skreddersy implementeringen av viktige helseanbefalinger som gjelder fem ulike kroniske sykdomsgrupper (depresjon hos eldre, multimorbiditet/ polyfarmasi, overvekt, KOLS og kardiovaskulær sykdom)

(30). I alle landene bruker man den samme metoden for skreddersøm:

1. Identifisere viktige faktorer som hemmer eller fremmer at anbefalingene tas i bruk i helsevesenet, samt teste ut metoder som er egnet for å identifisere disse determinantene for praksis,

2. På bakgrunn av de identifiserte determinantene, drøfte med forskjellige grupper av forskere, helsepersonell og brukere ulike måter å implementere anbefalingene og

3. Implementere anbefalingene ved å ta hensyn til de identifiserte determinantene.

Det siste vil vi gjøre i form av klynge-randomiserte studier. Erfaringene fra TICD vil kunne gjøre oss i stand til å trekke konklusjoner om metodens gyldighet på tvers av de ulike sykdomsgrupper og de ulike landenes helsesystemer. 
heller enn en myndighetsperson, at det skjer mer enn en gang og gis både muntlig og skriftlig, samt at det gis med klare mål og en handlingsplan.

Selv om effektene av implementeringsstudier oftest er små til moderate, kan de likevel være viktige.

\section{NOEN INITIATIV FOR Å FREMME IMPLEMENTERINGSFORSKNING}

\section{The Cochrane Effective Practice and Organisation of Care Group (EPOC)}

The Cochrane Effective Practice and Organisation of Care Group (EPOC) er en av vel 50 tematiske grupper i Cochrane-samarbeidet. EPOC har ansvaret for systematiske oversikter som evaluerer tiltak for å forbedre helsearbeideres praksis og organiseringen av helsetjenestene. Tiltakene kan være rettet mot helsepersonell, som for eksempel etterutdanning, praksisbesøk eller praksisregistering og tilbakemelding, eller tiltakene kan være rettet mot systemnivået, som organisatoriske, regulatoriske og økonomiske intervensjoner som kan hjelpe helsepersonell til å levere helsetjenester på en bedre måte. EPOC-oversiktene er kategorisert i oversikter som gjelder implementeringsstrategier, finansielle ordninger og ledelse/styring. Kunnskapssenteret huser en norsk EPOC-satellitt, som ble etablert i 2006 for å støtte produksjonen av EPOC-oversikter som er relevante for lav- og mellominntektsland.

\section{Implementation Research Platform (WHO)}

The Implementation Research Platform (IRF) ble lansert i 2010 i forbindelse med det første Global Symposium on Health Systems Research. IRF er et samarbeid mellom fem programmer og avdelinger i WHO. IRF har støtte fra UK Department for International Development (DFID), the Swedish International Development Cooperation Agency (Sida) samt Norad. IRP støtter forskning for å bedre tilgangen til tiltak som er viktige for å oppnå FNs helserelaterte tusenårsmål.

\section{European Science Foundation}

De medisinske forskningsrådene i Europa har gjennom European Science Foundation (ESF) utarbeidet rapporten "Implementation of medical research in clinical practice" (40). Rapporten beskriver først og fremst implementeringen, og i liten grad implementeringsforskningen. Den inneholder en serie anbefalinger for å styrke implementering av medisinsk forskning i klinisk praksis.

\section{Implementation Science}

Implementation Science er et spesialtidsskrift for implementeringsforskning etablert i 2006 (41). Siden oppstart har tidsskriftet mottatt en økende mengde manuskripter, og det har vært behov for å klargjøre hva implementeringsforskning er og ikke er (42).

\section{Knowledge Translation Canada}

Knowledge Translation Canada (KT Canada) er et nettverk av canadiske eksperter som arbeider for å håndtere og forske på det de karakteriserer som den største utfordringen i dagens helsetjeneste: gapet mellom den helseforskningen som utføres og bruken av resultatene i daglige beslutninger i helsetjenestene. Det canadiske helseforskningsinstituttet CIHR har som sin oppgave å omforme canadisk helsetjeneste, bl.a. gjennom å bidra til at «the results of research are transformed into policies, practices, procedures, products and services" (43).

\section{Nordic Implementation Interest Group}

Også i de nordiske land er det økende interesse for evaluering av kvalitetsforbedringsarbeid og for implementering og implementeringsforskning. Det var nær 400 deltakere på en nordisk konferanse om implementering av kunnskapsbasert praksis i Linköping i februar 2013. Miljøet i Linköping underviser i implementeringsforskning og har gitt ut en leseverdig bok om emnet (23). Nordic Implementation Interest Group er etablert for å undersøke spørsmål knyttet til kvalitetsforbedring og implementering av kunnskapsbasert praksis i helse- og sosialtjenestene, og på undervisningsfeltet. Avdeling for kunnskapsbasert praksis ved Høgskolen i Bergen har ansvaret for den neste nordiske konferansen om implementering i februar 2015.

\section{IMPLEMENTERINGSFORSKNING I NORGE}

Implementeringsforskningen har ingen sterk tradisjon i Norge. Vi har likevel flere spredte eksempler på norske implementeringsstudier, både fra primær- og spesialisthelsetjenesten. Flere av disse er inkludert i systematiske oversikter fra EPOC og andre Cochranegrupper. Nedenfor omtaler vi noen av disse studiene.

To norske studier er inkludert $\mathrm{i}$ en systematisk Cochrane-oversikt med til sammen 31 studier over effektene av å organisere sykehusbehandlingen ved akutt slag i såkalte slagenheter (44-46). Organisert slagenhet er en spesialenhet der pasienter med akutt hjerneslag får tverrfaglig vurdering og behandling av et team av sykepleiere, leger samt fysio- og ergoterapeuter som er spesialisert for oppgaven. Oversikten konkluderte med at pasienter med akutt hjerneslag som var behandlet $\mathrm{i}$ slagenhet, i stedet for en vanlig medisinsk avdeling, har økt sannsynlighet for å være i live, bli utskrevet til hjemmet og være uavhengige av hjelp ett år etter slaget (46).

Hetlevik undersøkte i sin doktoravhandling effektene av å implementere retningslinjer for hypertensjon i allmennpraksis ved bruk av et databasert klinisk beslutningsstøttesystem og en spesifikk implementeringsstrategi (47). Tjueni legesentre med i alt 53 leger og 2239 pasienter ble randomisert til intervensjons- og kontrollgruppe. Hetlevik fant ingen effekt av intervensjonen på legers praksis, som var hovedutfallet, og heller ingen viktig klinisk effekt på pasientutfall (blodtrykk, kolesterol, risikoskår for infarkt, andelen røykere).

Garåsen og medarbeidere gjennomførte en studie der 142 pasienter over 60 år innlagt St. Olavs Hospital for akutt sykdom eller forverring av kronisk sykdom 
ble randomisert til enten slutt- og etterbehandling på en intermediæravdeling $i$ et sykehjem eller på sykehuset $(48,49)$. Sluttbehandling på intermediært nivå i et sykehjem medførte færre reinnleggelser, at flere pasienter klarte seg selv uten kommunale omsorgstjenester og lavere dødelighet. Samtidig var behandlingstilbudet kostnadseffektivt.

Telstad og medarbeidere undersøkte effekten av å lære opp personalet i sykehjem for å redusere bruk av tvangsmidler blant urolige demente pasienter (50). Fire sykehjem i Stavanger ble randomisert til intervensjonseller kontrollgruppe. Intervensjonen bestod av et seminar over en dag, med oppfølging av veiledning en time per måned i seks måneder. Forfatteren konkluderte at intervensjonen førte til redusert bruk av tvang overfor institusjonaliserte demente.

Jordhøy og medarbeidere undersøkte effektene av en intervensjon for at pasienter med uhelbredelig kreftsykdom kunne bo lenger i hjemmet og dø hjemme om de ønsket det (51). Intervensjonen førte til at flere av pasientene i intervensjonsgruppen døde i sine hjem, men det var ingen forskjell i tiden pasientene bodde hjemme.

Brattebø og medarbeidere introduserte retningslinjer for leger og sykepleiere med et skåringssystem for å roe ned pasienter med behov for ventilering (52). Effektene ble evaluert ved en tidsserieanalyse, og forfatterne konkluderte med at disse enkle retningslinjene reduserte behovet for mekanisk ventilering med nesten $30 \%$. De understrekte imidlertid også at behovet for støtte i endringsprosessen ikke må undervurderes.

Lagerløv undersøkte i sin doktoravhandling effektene av å forbedre medikamentforskrivning ved astma og urinveisinfeksjoner ved hjelp av gruppediskusjoner om retningslinjene og feedback (53). Det å diskutere retningslinjene i en gruppe ga legene et grunnlag for å vurdere om behandlingen av individuelle pasienter var akseptabel eller ikke, og dette førte til at en større andel av pasientene fikk behandling i tråd med retningslinjene $\mathrm{i}$ intervensjonsgruppen sammenliknet med kontrollgruppen.

Kollegabasert terapiveiledning (KTV) er hovedprosjektet ved Allmennmedisinsk forskningsenhet Oslo. KTV-prosjektet er en stor klyngerandomisert intervensjonsstudie for å forbedre allmennlegers medikamentforskrivning innen to terapiområder, legemidler til eldre og antibiotika ved luftveisinfeksjoner $(54,55)$. PhD kandidatene Rognstad og Gjelstad har ledet disse studiene, veiledet av Jørund Straand og Morten Lindbæk. En sammensatt intervensjon bestående av besøk av en kollegakonsulent $\mathrm{i}$ fastlegenes etterutdanningsgrupper, tilbakemeldinger på egen forskrivningspraksis før og etter kurset, samt regionale dagskurs førte til mer rasjonell forskrivning både av antibiotika ved luftveisinfeksjoner (56) og av legemidler til eldre (57).

\section{IMPLEMENTERINGSFORSKNING FRA FORSKERE VED KUNNSKAPSSENTERET}

Arild Bjørndal inviterte Andy Oxman til Gruppe for helsetjenesteforskning ved Folkehelsa i 1994, og disse to var sentrale når det gjaldt å utvikle interessen for EBM og implementeringsforskning i Norge, bl.a. ved å rekruttere og veilede stipendiater som hadde dette som temaer for sine doktoravhandlinger. Flottorp og Fretheim utviklet og evaluerte skreddersydde intervensjoner for å implementere retningslinjer i allmennpraksis $(28,29,58-61)$. Forsetlund undersøkte om opplæring av samfunnsmedisinere i kunnskapsbasert praksis påvirket deres måte å jobbe på (62-65).

Glenton utviklet og evaluerte informasjon til ryggpasienter gjennom prosjektet RyggInfo (66-68). Carling gjennomførte internettbaserte studier og testet ut ulike måter å presentere informasjon på (69-72), mens designeren Rosenbaum blant annet benyttet brukertesting for å utvikle bedre metoder for å formidle resultater av oppsummert forskning (73-75).

Gjennom EU-prosjektet Developing and Evaluating Communication Strategies to Support Informed Decisions and Practice Based on Evidence (DECIDE) (76) bidrar forskere ved Kunnskapssenteret til å utvikle og evaluere metoder for å sikre effektiv kommunikasjon om resultater fra forskning og kunnskapsbaserte anbefalinger rettet mot både helsepersonell, beslutningstakere og ledere $\mathrm{i}$ helsetjenesten, så vel som pasienter og allmennheten generelt.

\section{SEKUND FRFORSKNING - SYSTEMATISKE OVERSIKTER OM IMPLEMENTERINGS- FORSKNING}

Forskere ved Kunnskapssenteret driver i liten grad primærforskning, men er først og fremst engasjert i å utarbeide systematiske oversikter. Dette gjelder også på feltet implementeringsforskning. Forskere på Kunnskapssenteret har medvirket til en rekke Cochraneoversikter over ulike implementeringstiltak. Det er også en lang liste over rapporter fra Kunnskapssenteret som gjelder effekter av kvalitetsforbedrings- og implementeringstiltak. Etterspørselen etter rapporter fra Kunnskapssenteret som handler om kvalitetsforbedring, organisering, ledelse og finansiering av helsetjenestene er økende, og det er særlig bestillinger fra Helsedirektoratet som har blitt prioritert.

\section{KONKLUSJON}

Implementeringsforskning, eller forskning om forbedring, er en ung vitenskap. Formålet med denne forskningen er å redusere gapet mellom forskning og praksis, ved å utvikle og evaluere tiltak som kan sikre at behandlingen som pasientene mottar er basert på oppdatert forskning, at den er omsorgsfull og av god kvalitet. Det er nødvendig å øke kapasitet og kompetanse for implementering og kvalitetsforbedring $\mathrm{i}$ helsetjenestene, samt i forskningsmetoder for å evaluere denne virksomheten. For å oppnå dette må det utvikles et partnerskap mellom helsepersonell, ledere i helsetjenesten med ansvar for å sikre kvalitet i tjenestene, andre beslutningstakere og implementeringsforskere. Da kan implementeringsforskningen gi viktige bidrag til kunnskapsbaserte helse- og omsorgstjenester. 


\section{REFERANSER}

1. Haugum M, Bjertnæs ØA, Iversen HH, Lindahl AK, Nylenna M. Commonwealth Fund-undersøkelse blant allmennleger i 10 land: norske resultater i 2012 og utvikling siden 2009. Rapport fra Kunnskapssenteret nr. 11-2012. Oslo: Nasjonalt kunnskapssenter for helsetjenesten, 2012.

2) Overdiagnostikk og overbehandling. Rapport fra Helsedirektoratet til Helse- og omsorgsdepartementet. Oslo: Helsedirektoratet, 2013.

3. Tam VC, Knowles SR, Cornish PL, Fine N, Marchesano R, Etchells EE. Frequency, type and clinical importance of medication history errors at admission to hospital: a systematic review. CMAJ 2005; 173: 510-5.

4. Bivirkningsrapport 2012. Oslo: Statens legemiddelverk, 2012.

5. Thomsen LA, Winterstein AG, Sondergaard B, Haugbolle LS, Melander A. Systematic review of the incidence and characteristics of preventable adverse drug events in ambulatory care. Ann Pharmacother 2007; 41: 1411-26.

6. McGlynn EA, Asch SM, Adams J, Keesey J, Hicks J, DeCristofaro A, et al. The Quality of Health Care Delivered to Adults in the United States. NEJM 2003; 348: 2635-45.

7. Runciman WB, Hunt TD, Hannaford NA, Hibbert PD, Westbrook JI, Coiera EW, et al. CareTrack: assessing the appropriateness of health care delivery in Australia. Med J Aust 2012; 197: 100-5.

8. Vandvik PO, Berg R, Vist G. En ny generasjon troverdige kliniske retningslinjer. Norsk Epidemiologi 2013; 23: $197-204$.

9. Institute of Medicine. Clinical practice guidelines we can trust. Washington DC: National Academy Press, 2011.

10. Treweek S, Flottorp S, Fretheim A, Havelsrud K, Kristoffersen DT, Oxman A, et al. Retningslinjer for allmennpraksis - blir de lest og blir de brukt? Tidsskr Nor Legeforen 2005; 125: 300-3.

11. Grol R, Berwick DM, Wensing M. On the trail of quality and safety in health care. BMJ 2008; 336: 74-6.

12. Remme JH, Adam T, Becerra-Posada F, D'Arcangues C, Devlin M, Gardner C, et al. Defining research to improve health systems. PLoS Med 2010; 7(11): e1001000.

13. McKibbon KA, Lokker C, Wilczynski NL, Ciliska D, Dobbins M, Davis DA, et al. A cross-sectional study of the number and frequency of terms used to refer to knowledge translation in a body of health literature in 2006: a Tower of Babel? Implement Sci 2010; 5: 16.

14. Wensing M, Grimshaw JM, Eccles MP. Does the world need a scientific society for research on how to improve healthcare? Implement Sci 2012; 7: 10.

15. Woolf SH. The meaning of translational research and why it matters. JAMA 2008; 299: 211-3.

16. Six-third World Health Assembly: WHO's role and responsibilities in health research. Document A63/21 approved on May 21, 2010. http://apps.who.int/gb/ebwha/pdf_files/WHA63/A63_R21-en.pdf (28.10.2013).

17. Pan American Health Organization: PAHO's Policy on Research for Health. Approved at the 61st session of the Directing Council, 2009. http://new.paho.org/hq/dmdocuments/2010/RESEARCHpolicyBKLETeng web.pdf (28.10.2013).

18. European Science Foundation: Implementation of medical research in clinical practice. Strasbourg: European Science Foundation, 2011. http://www.esf.org/fileadmin/Public_documents/Publications/Implem _ MedReseach_ClinPractice.pdf (28.10.2013).

19. Tetroe JM, Graham ID, Foy R, Robinson N, Eccles MP, Wensing M, et al. Health research funding agencies' support and promotion of knowledge translation: an international study. Milbank Q 2008; 86: 125-55.

20. Rogers EM. Diffusions of innovations, 5th edn. New York: The Free Press, 2003.

21. Saetren H. Facts and myths about research on public policy implementation: out-of-fashion, allegedly dead, but still very much alive and relevant. Policy Studies Journal 2005; 33: 559-82.

22. Pressman JL, Wildavsky A. Implementation: How Great Expectations in Washington are Dashed in Oakland; Or, Why It's Amazing that Federal Programs Work at All, this Being a Saga of the Economic Development Administration as Told by Two Sympathetic Observers who Seek to Build Morals on a Foundation of Ruined Hopes. The Oakland Project. 3rd edn. Berkeley and Los Angeles: University of California Press, 1984.

23. Implementering. Teori og tillämpning inom hälso- och sjukvård. Lund: Studentlitteratur AB, 2010.

24. Eccles MP, Armstrong D, Baker R, Cleary K, Davies H, Davies S, et al. An implementation research agenda. Implement Sci 2009; 4: 18.

25. Marshall M, Pronovost P, Dixon-Woods M. Promotion of improvement as a science. Lancet 2013; 381: 41921.

26. Greenhalgh T, Wieringa S. Is it time to drop the 'knowledge translation' metaphor? A critical literature review. J R Soc Med 2011; 104: 501-9.

27. Graham ID, Logan J, Harrison MB, Straus SE, Tetroe J, Caswell W, et al. Lost in knowledge translation: time for a map? J Contin Educ Health Prof 2006; 26: 13-24.

28. Flottorp S, Oxman AD. Identifying barriers and tailoring interventions to improve the management of urinary tract infections and sore throat: a pragmatic study using qualitative methods. BMC Health Serv Res 2003; 3:3. 
29. Flottorp S, Oxman AD, Havelsrud K, Treweek S, Herrin J. Cluster randomised controlled trial of tailored interventions to improve the management of urinary tract infections in women and sore throat. BMJ 2002; 325: 367.

30. Wensing M, Oxman A, Baker R, Godycki-Cwirko M, Flottorp S, Szecsenyi J, et al. Tailored implementation for chronic diseases (TICD): A project protocol. Implement Sci 2011; 6: 103.

31. Flottorp SA, Oxman AD, Krause J, Musila NR, Wensing M, Godycki-Cwirko M, et al. A checklist for identifying determinants of practice: A systematic review and synthesis of frameworks and taxonomies of factors that prevent or enable improvements in healthcare professional practice. Implement Sci 2013; 8: 35.

32. Wensing M, Bosch M, Foy R, van der Weijden T, Eccles M, Grol R. Factors in theories on behaviour change to guide implementation and quality improvement in health care. Nijmegen: Centre for Quality of Care Research (WOK), 2005.

33. Michie S, Johnston M, Abraham C, Lawton R, Parker D, Walker A. Making psychological theory useful for implementing evidence based practice: a consensus approach. Qual Saf Health Care 2005; 14: 26-33.

34. Weiner BJ. A theory of organizational readiness for change. Implement Sci 2009; 4: 67.

35. Oxman AD, Thomson MA, Davis DA, Haynes RB. No magic bullets: a systematic review of 102 trials of interventions to improve professional practice. Can Med Assoc J 1995; 153: 1423-31.

36. Bero LA, Grilli R, Grimshaw JM, Harvey E, Oxman AD, Thomson MA. Closing the gap between research and practice: an overview of systematic reviews of interventions to promote the implementation of research findings. The Cochrane Effective Practice and Organization of Care Review Group. BMJ 1998; 317: 465-8.

37. Grimshaw JM, Shirran L, Thomas R, Mowatt G, Fraser C, Bero L, et al. Changing provider behavior: an overview of systematic reviews of interventions. Med Care 2001; 39 (8 Suppl 2): II2-45.

38. Grimshaw JM, Thomas RE, Maclennan G, Fraser C, Ramsay CR, Vale L, et al. Effectiveness and efficiency of guideline dissemination and implementation strategies. Health Technol Assess 2004; 8 (6): iii-72.

39. Ivers N, Jamtvedt G, Flottorp S, Young JM, Odgaard-Jensen J, French SD, et al. Audit and feedback: effects on professional practice and healthcare outcomes. Cochrane Database Syst Rev 2012; 6: CD000259.

40. Implementation of medical research in clinical practice. Strasbourg: European Science Foundation, 2011.

41. Implementation Science, www.implementationscience.com/ (19.4.2013).

42. Eccles MP, Foy R, Sales A, Wensing M, Mittman B. Implementation Science six years on - our evolving scope and common reasons for rejection without review. Implement Sci 2012; 7: 71.

43. The Canadian Institutes of Health Research (CIHR) - Our Mission, www.cihr-irsc.gc.ca/e/7263.html (28.10.2013).

44. Indredavik B, Bakke F, Slordahl SA, Rokseth R, Haheim LL. Treatment in a combined acute and rehabilitation stroke unit: which aspects are most important? Stroke 1999; 30: 917-23.

45. Ronning OM, Guldvog B. Stroke unit versus general medical wards, II: neurological deficits and activities of daily living: a quasi-randomized controlled trial. Stroke 1998; 29: 586-90.

46. Stroke Unit Trialists' Collaboration. Organised inpatient (stroke unit) care for stroke. Cochrane Database Syst Rev 2007; (4): CD000197.

47. Hetlevik I. The role of clinical guidelines in cardiovascular risk intervention in general practice. Trondheim: Institutt for samfunnsmedisin, Norges teknisk-naturvitenskapelige universitet, 1999.

48. Garasen H, Windspoll R, Johnsen R. Intermediate care at a community hospital as an alternative to prolonged general hospital care for elderly patients: a randomised controlled trial. BMC Public Health 2007; 7: 68.

49. Garasen H, Windspoll R, Johnsen R. Long-term patients' outcomes after intermediate care at a community hospital for elderly patients: 12-month follow-up of a randomized controlled trial. Scand J Public Health 2008; 36: 197-204.

50. Testad I, Aasland AM, Aarsland D. The effect of staff training on the use of restraint in dementia: a singleblind randomised controlled trial. Int J Geriatr Psychiatry 2005; 20: 587-90.

51. Jordhøy MS, Fayers P, Saltnes T, Ahlner-Elmqvist M, Jannert M, Kaasa S. A palliative-care intervention and death at home: a cluster randomised trial. Lancet 2000; 356: 888-93.

52. Brattebø G, Hofoss D, Flaatten H, Muri AK, Gjerde S, Plsek PE. Effect of a scoring system and protocol for sedation on duration of patients' need for ventilator support in a surgical intensive care unit. BMJ 2002; 324 : 1386-9.

53. Lagerløv P, Loeb M, Andrew M, Hjortdahl P. Improving doctors' prescribing behaviour through reflection on guidelines and prescription feedback: a randomised controlled study. Qual Health Care 2000; 9: 159-65.

54. Straand J, Fetveit A, Rognstad S, Gjelstad S, Brekke M, Dalen I. A cluster-randomized educational intervention to reduce inappropriate prescription patterns for elderly patients in general practice - The Prescription Peer Academic Detailing (Rx-PAD) study [NCT00281450]. BMC Health Serv Res 2006; 6: 72.

55. Gjelstad S, Fetveit A, Straand J, Dalen I, Rognstad S, Lindbaek M. Can antibiotic prescriptions in respiratory tract infections be improved? A cluster-randomized educational intervention in general practice - the Prescription Peer Academic Detailing (Rx-PAD) Study [NCT00272155]. BMC Health Serv Res 2006; 6: 75. 
56. Gjelstad S, Hoye S, Straand J, Brekke M, Dalen I, Lindbaek M. Improving antibiotic prescribing in acute respiratory tract infections: cluster randomised trial from Norwegian general practice (prescription peer academic detailing (Rx-PAD) study). BMJ 2013; 347: f4403.

57. Rognstad S, Brekke M, Fetveit A, Dalen I, Straand J. Prescription peer academic detailing to reduce inappropriate prescribing for older patients: a cluster randomised controlled trial. Br J Gen Pract 2013; 63: 554-62.

58. Flottorp S, Havelsrud K, Oxman AD. Process evaluation of a cluster randomized trial of tailored interventions to implement guidelines in primary care-why is it so hard to change practice? Fam Pract 2003; 20: 333-9.

59. Fretheim A, Oxman AD, Håvelsrud K, Treweek S, Kristoffersen, Bjørndal A. Rational Prescribing in Primary Care (RaPP-trial): a cluster-randomized trial of a tailored intervention. PLoS Med 2006; 3(6): e134.

60. Fretheim A, Oxman AD, Flottorp S. Improving prescribing of antihypertensive and cholesterol-lowering drugs: a method for identifying and addressing barriers to change. BMC Health Serv Res 2004 Oct 3; 4(1): 23.

61. Fretheim A, Havelsrud K, Oxman AD. Rational Prescribing in Primary care (RaPP): process evaluation of an intervention to improve prescribing of antihypertensive and cholesterol-lowering drugs. Implement Sci 2006; 1: 19 .

62. Forsetlund L, Bjorndal A. The potential for research-based information in public health: identifying unrecognised information needs. BMC Public Health 2001; 1(1): 1.

63. Forsetlund L, Bjørndal A. Identifying barriers to the use of research faced by public health physicians in Norway and developing an intervention to reduce them. J Health Serv Res Policy 2002; 7: 10-8.

64. Forsetlund L, Bradley P, Forsen L, Nordheim L, Jamtvedt G, Bjorndal A. Randomised controlled trial of a theoretically grounded tailored intervention to diffuse evidence-based public health practice [ISRCTN23257060]. BMC Med Educ 2003; 3: 2.

65. Forsetlund L, Talseth KO, Bradley P, Nordheim L, Bjorndal A. Many a slip between cup and lip. Process evaluation of a program to promote and support evidence-based public health practice. Eval Rev 2003; 27: 179-209.

66. Glenton C. Developing patient-centred information for back pain sufferers. Health Expect 2002; 5: 319-29.

67. Glenton C. Chronic back pain sufferers - striving for the sick role. Soc Sci Med 2003; 57: 2243-52.

68. Glenton C, Paulsen EJ, Oxman AD. Portals to Wonderland: health portals lead to confusing information about the effects of health care. BMC Med Inform Decis Mak 2005; 5: 7.

69. Carling C, Kristoffersen DT, Herrin J, Treweek S, Oxman AD, Schunemann H, et al. How should the impact of different presentations of treatment effects on patient choice be evaluated? A pilot randomized trial. PLoS ONE 2008; 3 (11): e3693.

70. Carling CL, Kristoffersen DT, Flottorp S, Fretheim A, Oxman AD, Schunemann HJ, et al. The effect of alternative graphical displays used to present the benefits of antibiotics for sore throat on decisions about whether to seek treatment: a randomized trial. PLoS Med 2009; 6 (8): e1000140.

71. Carling CL, Kristoffersen DT, Montori VM, Herrin J, Schunemann HJ, Treweek S, et al. The effect of alternative summary statistics for communicating risk reduction on decisions about taking statins: a randomized trial. PLoS Med 2009; 6 (8): e1000134.

72. Carling CL, Kristoffersen DT, Oxman AD, Flottorp S, Fretheim A, Schunemann HJ, et al. The effect of how outcomes are framed on decisions about whether to take antihypertensive medication: a randomized trial. PLoS ONE 2010; 5 (3): e9469.

73. Rosenbaum SE, Glenton C, Cracknell J. User experiences of evidence-based online resources for health professionals: user testing of The Cochrane Library. BMC Med Inform Decis Mak 2008; 8: 34.

74. Rosenbaum SE, Glenton C, Nylund HK, Oxman AD. User testing and stakeholder feedback contributed to the development of understandable and useful Summary of Findings tables for Cochrane reviews. J Clin Epidemiol 2010; 63: 607-19.

75. Rosenbaum SE, Glenton C, Oxman AD. Summary-of-findings tables in Cochrane reviews improved understanding and rapid retrieval of key information. J Clin Epidemiol 2010; 63: 620-6.

76. Developing and Evaluating Communication Strategies to Support Informed Decisions and Practice Based on Evidence (DECIDE). http://www.decide-collaboration.eu/ (28.10.2013). 